\title{
FRACTIONATION OF THE $N$-HEXANE EXTRACT OF GARCINIA BANCANA MIQ. (MANGGIS \\ HUTAN) LEAVES AND ITS ANTIOXIDANT ACTIVITY BASED ON 1,1-DIPHENYL-2- PICRYLHYDRAZYL AND FERRIC REDUCING ANTIOXIDANT POWER ASSAYS
}

\author{
DEWI KUMALA PUTRI, BERNA ELYA*, NURAINI PUSPITASARI \\ Department of Pharmacy, Faculty of Pharmacy, Universitas Indonesia, Depok 16424, Indonesia. Email: berna.elya@farmasi.ui.ac.id \\ Received: 19 June 2018, Revised and Accepted: 29 September 2018 and 25 October 2018
}

ABSTRACT

Objective: To assess the antioxidant activity from another part of the plant, in this study, leaf extracts in $n$-hexane were fractionated.

Methods: Ten fractions were obtained and tested in vitro for antioxidant activity using two methods, 1,1-diphenyl-2-picrylhydrazyl (DPPH) and ferric reducing antioxidant power (FRAP), to identify the most active fraction.

Results: The $\mathrm{IC}_{\mathbf{5 0}}$ of the most active fraction was $36.24 \mu \mathrm{g} / \mathrm{mL}$ using the DPPH method, and the $\mathrm{EC}_{\mathbf{5 0}}$ was $39.54 \mu \mathrm{g} / \mathrm{mL}$ using the FRAP method. The most active fraction was also shown to contain terpenoids.

Conclusion: The most active fraction of an n-hexane extract of the leaves of Gacinia bancana Miq., which was tested by both DPPH and FRAP methods had antioxidant activities with $\mathrm{IC}_{\mathbf{5 0}}$ and $\mathrm{EC}_{\mathbf{5 0}}$ values of $36.2482 \mu \mathrm{g} / \mathrm{mL}$ and $39.5442 \mu \mathrm{g} / \mathrm{mL}$, respectively. Phytochemical screening showed that active fraction contains terpenoids.

Keywords: 1,1-diphenyl-2-picrilhydrazyl, Antioxidant, Ferric reducing antioxidant power, Gacinia bancana Miq.

(C) 2018 The Authors. Published by Innovare Academic Sciences Pvt Ltd. This is an open access article under the CC BY license (http://creativecommons. org/licenses/by/4. 0/) DOI: http://dx.doi.org/10.22159/ijap.2018.v10s1.90

\section{INTRODUCTION}

Free radicals are molecules containing one or more unpaired electrons in their outermost molecular orbitals. Excess free radicals in the body can lead to degenerative diseases such as stroke, cancer, and heart attack [1]. To overcome the problem of free radicals, the body requires antioxidants that can scavenge free radical compounds and thus prevent the damage caused by the chain reaction of free radical formation elicited by oxidative stress [2]. Antioxidants are basically divided into two types: Natural and synthetic. Commonly used synthetic antioxidants include butylated hydroxytoluene, butylated hydroxyanisole, propyl gallate, and tertiary butyl hydroquinone, which are all carcinogenic and hence harmful [3-5]. Hence, the use of natural antioxidants is considered more suitable with respect to human health.

Some species of Garcinia have strong antioxidant activity and are a source of natural antioxidants. Methanol, ethyl acetate, and n-hexane extracts of Garcinia kydia Roxb. leaves exhibited $\mathrm{EC}_{50}$ values on ferric reducing antioxidant power (FRAP) assay of 18.4, 12.4, and $31.3 \mu \mathrm{g} / \mathrm{mL}$, respectively [6]. Similarly, methanol, ethyl acetate, and n-hexane extracts of Gacinia bancana Miq. leaves exhibited antioxidant activity with $\mathrm{IC}_{50}$ values of $26.9,51.3$, and $19.9 \mu \mathrm{g} / \mathrm{mL}$ [7].Another with an n-hexane extract of $G$. bancana Miq stem bark tested in a 1,1-diphenyl2-picrylhydrazyl (DPPH) produced an $\mathrm{IC}_{50}$ value of $17 \mu \mathrm{g} / \mathrm{mL}$ and identified the presence of bancanon, a triterpenoid, that is suspected to have antioxidant potential [5]. Other compounds found in many species of Garcinia, namely xanthone, benzophenone, and triterpenoid, all possess antibiotic, anticancer, and antioxidant activities [7].

This previous research indicates that the $\mathrm{IC}_{50}$ of n-hexane extracts of G. bancana Miq. is smaller than that of ethyl acetate and methanol extracts. Therefore, in this study, n-hexane G. bancana Miq. leaf extracts were fractionated using column chromatography to obtain the most active antioxidant by in vitro screening using the DPPH and FRAP methods. Phytochemical screening of the most active fraction was then carried out to identify the active ingredient.

\section{METHODS}

Working procedures included material preparation, fractionation, and antioxidant activity testing by determining $\mathrm{IC}_{50}$ using DPPH and FRAP assays to identify the active fraction and determination of the chemical content of the active fraction of an n-hexane extract of $G$. bancana Miq. leaves by phytochemical screening

\section{RESULTS AND DISCUSSION}

\section{Chromatography}

Column chromatography produced 310 fractions that were evaporated, subjected to thin-layer chromatography (TLC) on a silica gel plate, stained from KLT, and examined under ultraviolet (UV) light. Fractions containing the same spots were combined into the same fraction, and all fractions were then dried and weighed before testing. The weights of the resulting ten fractions are shown in Table 1.

\section{Preliminary testing with DPPH spray}

The ten samples were run on a $\mathrm{F}_{254}$ silica gel plate and then sprayed with a $100 \mu \mathrm{g} / \mathrm{mL}$ DPPH solution. Positive antioxidant results were indicated by the formation of a pale-yellow circle with a purple background [8].

Of the ten fractions, no antioxidant activity was found in fractions 1,2 , 3,4 , and 5 , while the $6^{\text {th }}$ fraction produced very small yellow spot. The highest antioxidant activity was found in the $7^{\text {th }}$ and $8^{\text {th }}$ fractions, while the yellow color faded and shrunk again in the $9^{\text {th }}$ and $10^{\text {th }}$ fractions. These results, however, were not conclusive and further testing was required.

\section{DPPH antioxidant activity testing}

Antioxidant activity was first tested using quercetin as a reference standard at five different final concentrations of $0.25,0.5,1,1.5$, and $2 \mu \mathrm{g} / \mathrm{mL}$ and by measurement of absorbance at $517 \mathrm{~nm}$. The determined $\mathrm{IC}_{50}$ value was $1.262 \mu \mathrm{g} / \mathrm{mL}$, and the calibration curve is shown in Fig. 1. 
Next, fractions 7,8 , and 9, which had been preliminarily tested qualitatively and exhibited antioxidant activity, were tested more extensively using DPPH. In this spectrophotometric assay, smaller absorption indicates higher antioxidant activity.

Fraction 7 exhibited the smallest absorption and therefore the highest percentage of inhibition value of $28.03 \%$ among the three fractions tested, thereby showing the greatest antioxidant activity. The data for the three fractions are presented in Table 2.

Fraction 7 was then analyzed to determine its $\mathrm{IC}_{50}$ fraction 7 using different concentrations, namely $72.03,102.9,123.48,154.35$, and $185.22 \mu \mathrm{g} / \mathrm{mL}$, with final concentration based on the dilution factors at the cuvette as $18.0,25.73,30.87,38.59$, and $46.31 \mu \mathrm{g} / \mathrm{mL}$, respectively. This showed that most active fraction of the n-hexane extract $G$. bancana Miq. had an $\mathrm{IC}_{50}$ of $36.25 \mu \mathrm{g} / \mathrm{mL}$ (Table 3).

\section{FRAP antioxidant activity testing}

Antioxidant testing was repeated using the FRAP method to confirm the DPPH results. In contrast to the DPPH method, in the FRAP method, the samples with higher antioxidant also have the highest absorbance [9].

Quercetin was again used as a reference standard, with final concentrations of $1,2,3,4$, and $5 \mu \mathrm{g} / \mathrm{mL}$ producing an $\mathrm{EC}_{50}$ value of $2.61 \mu \mathrm{g} / \mathrm{mL}$ (Fig. 2)

The three fractions previously tested with DPPH were prepared at the same concentration of $100 \mu \mathrm{g} / \mathrm{mL}$, and uptake was measured using a UV-visible spectrophotometer at the optimum wavelength of $594 \mathrm{~nm}$. The concentration data and percentage of sample capacity are shown in Table 4.

The most active fraction was tested by using concentration 25.73, $36.02,51.45,67.91$, and $77.18 \mu \mathrm{g} / \mathrm{mL}$. The resulting data (Table 5) were used to generate an inhibition curve (Fig. 3). This showed that

Table 1: Fraction data result

\begin{tabular}{ll}
\hline Fraction & Weight extract (g) \\
\hline 1 & 0.0131 \\
2 & 4.6844 \\
3 & 0.8445 \\
4 & 2.0098 \\
5 & 0.3084 \\
6 & 0.9247 \\
7 & 5.3835 \\
8 & 1.3532 \\
9 & 0.3267 \\
10 & 7.0573 \\
\hline
\end{tabular}

Table 2: Concentrations and \%DPPH inhibition data for sample fractions

\begin{tabular}{lll}
\hline Fraction & Final concentration $(\boldsymbol{\mu g} / \mathbf{m L})$ & \% inhibition \\
\hline 7 & 25.725 & 28.03 \\
8 & 27.125 & 26.19 \\
9 & 27.25 & 3.45 \\
\hline
\end{tabular}

DPPH: 1,1-diphenyl-2-picrylhydrazyl the n-hexane leaf extract of $G$. bancana Miq. had an $\mathrm{EC}_{50}$ of $39.54 \mu \mathrm{g} / \mathrm{mL}$ when measured by the FRAP method.

\section{Phytochemical screening}

Phytochemical screening was carried out qualitatively using TLC, and the test results are shown in Table 6.

\section{Flavonoid test}

The flavonoid test used quercetin as a standard, and the plate was examined under $366 \mathrm{~nm}$ UV light. Red streaks and spots were observed in the sample that was different from the standard (Fig. 4).

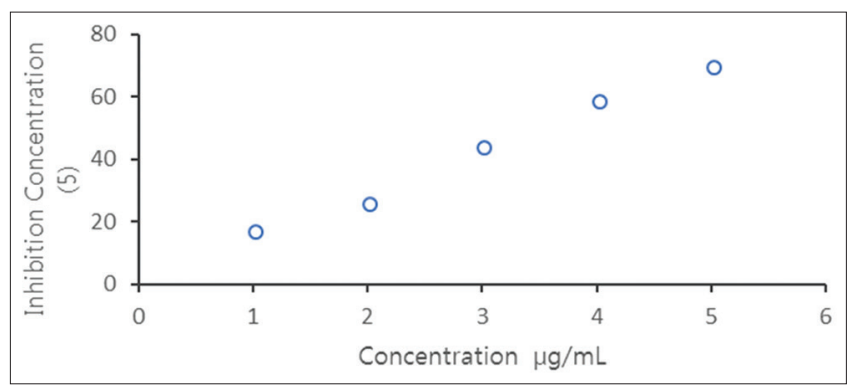

Fig. 1: Quercetin antioxidant activity curve using the 1,1-diphenyl2-picrylhydrazyl method

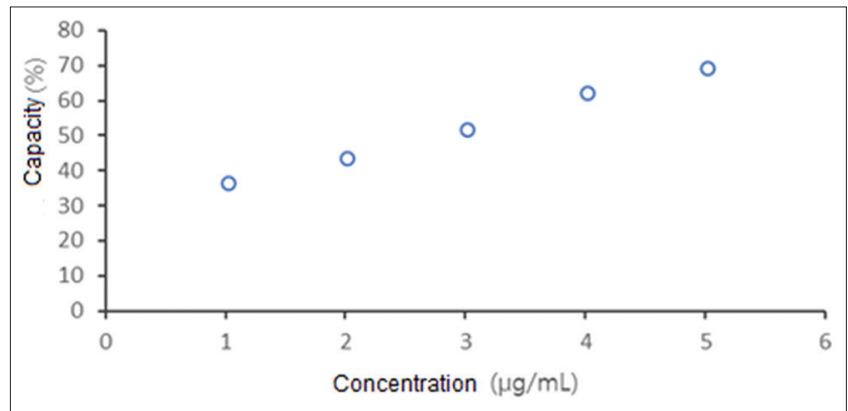

Fig. 2: Quercetin antioxidant activity curve by the ferric reducing antioxidant power method



Fig. 3: Most active fraction antioxidant activity curve using the ferric reducing antioxidant power method

Table 3: \%DPPH inhibitory data and $\mathrm{IC}_{50}$ of the most active fraction

\begin{tabular}{llll}
\hline Final concentration $(\boldsymbol{\mu g} / \mathbf{m L})$ & Inhibition $(\%)$ & Linear regression equation & IC $_{50}(\boldsymbol{\mu g} / \mathbf{m L})$ \\
\hline 18.00 & 34.05 & $\mathrm{y}=0.877 \mathrm{x}+18.2$ & 36.25 \\
25.72 & 39.43 & & \\
30.87 & 46.05 & & \\
38.58 & 53.84 & & \\
46.30 & 57.52 & & \\
\hline
\end{tabular}

DPPH: 1,1-diphenyl-2-picrylhydrazyl 


\section{Alkaloid test}

Tetrandrine is used as the standard in the alkaloid test. Spots should become visible after being sprayed by Dragendorff reagent, with positive results appearing as yellow spots (Fig. 5).

\section{Terpenoid test}

$\beta$-sitosterol was used as a standard for terpenoids The plate was run in a hexane and ethyl acetate solvent (9:1) and then sprayed with vanillin and $10 \% \mathrm{H}_{2} \mathrm{SO} 4$ in ethanol and heated (Fig. 6).

The study began with separation using column chromatography to produce ten fractions of an n-hexane leaf extract of $G$. bancana Miq (Table 1). A preliminary test with a DPPH spray was conducted to determine which fractions contained potential antioxidant activity. At this stage, the results were not conclusive because the spray reaction is only a supporting reaction and further quantitative testing was required in the form of standard antioxidant activity tests.

Quercetin is used as a reference standard in these tests because it is a powerful antioxidant that can protect body tissues from oxidative stress $[5,10]$. The quercetin $\mathrm{IC}_{50}$ determined using DPPH was $1.262 \mu \mathrm{g} / \mathrm{mL}$, which was in good agreement with a previous study that reported an $\mathrm{IC}_{50}$ value for quercetin of $1.565 \mu \mathrm{g} / \mathrm{mL}$ [8]. Based on previous research, DPPH measurements using UV-visible spectrophotometer also obtained maximum absorption at $517 \mathrm{~nm}[8,11-13]$.

The test conducted on the three fractions that exhibited the highest activity in the DPPH spray test showed that fraction 7 exhibited the highest activity and its $\mathrm{IC}_{50}$ was subsequently determined to be $36.248 \mu \mathrm{g} / \mathrm{mL}$. Furthermore, with decreasing absorption of DPPH, the radical capture activity increased [14]. In a previous study into the antioxidant activity of the same plant species, and using the same extraction solvent (n-hexane) except on $G$. bancana Miq stem bark, the DPPH method produced an IC of $17.78 \mu \mathrm{g} / \mathrm{mL}$. The difference in $\mathrm{IC}_{50}$ values may be due to differences in the plant parts tested or in the equipment and materials used for testing. Nevertheless, the $\mathrm{IC}_{50}$ values obtained still exhibited very strong antioxidant activity because they were below $50 \mu \mathrm{g} / \mathrm{mL}$ [15].

More than one method is used to test the antioxidant capacity of the extract fraction due to the complex nature of phytochemical compounds [16]. The FRAP method was used to supplement and reinforce the results obtained using the DPPH method.

FRAP testing also used quercetin as a reference standard and a UV-visible spectrophotometer set to an optimum wavelength of $594 \mathrm{~nm}$, in contrast to previous research, which used $593 \mathrm{~nm}[17,18,19]$. This may be due to differences in the equipment used. The quercetin $\mathrm{EC}_{50}$ obtained was $2.61 \mu \mathrm{g} / \mathrm{mL}$, which was consistent with previous in vitro research reporting a value of $2.4 \mu \mathrm{g} / \mathrm{mL}$ [20].

In contrast to the DPPH method, the FRAP method showed good antioxidant activity for samples with highest absorbance [9]. FRAP testing also showed that fraction 7 had the highest antioxidant activity, in agreement with the DPPH method. Thus, it is likely that fraction 7 had the best antioxidant activity, and hence, its $\mathrm{EC}_{50}$ was determined.

The FRAP method is the only method that measures antioxidants and reductants in a sample directly, while other methods measure antioxidant activity indirectly by measuring free radical inhibition produced in the solution and the results depend on the reactive species being used [18, 21-23]. Therefore, the value of the result of the reduction in FRAP is determined by the value of $\mathrm{EC}_{50}$ (Fig. 2 and Table 5).

Table 4: Concentration and percentage sample capacity data

\begin{tabular}{lll}
\hline Fraction & Final concentration $(\boldsymbol{\mu g} / \mathbf{m L})$ & Capacity percentage $(\%)$ \\
\hline 7 & 51.45 & 54.53 \\
8 & 54.25 & 50.99 \\
9 & 54.5 & 51.53 \\
\hline
\end{tabular}

FRAP testing produces an $\mathrm{EC}_{50}$ of $39.54 \mu \mathrm{g} / \mathrm{mL}$. Prior research on the antioxidant activity of the Garcinia genus using the FRAP method showed that an n-hexane leaf extract of G. kydia Roxb. had an $\mathrm{EC}_{50}$ of $31.26 \mu \mathrm{g} / \mathrm{mL}$, which was greater than that of ethyl acetate and methanol extracts, which had $\mathrm{EC}_{50}$ values of 12.389 and $18.448 \mu \mathrm{g} / \mathrm{mL}$, respectively [6]. This is because the Garcinia species differed from the one used in this study, so the compounds contained in the extracts may have been different

Possible components of the most active fraction (Fraction 7) were identified by TLC. Flavonoid testing used quercetin as a standard because quercetin is a flavonol [10]. After elution, the spots are not clearly visible and hence need spraying with $\mathrm{AlCl}_{3}$ for viewing under a $366 \mathrm{~nm}$ UV light bulb [24]. The sample contained red streaks and spots that were different from the standard (Fig. 4). This is likely because the sample was derived from a chlorophyll-containing leaf extract so and so chlorophyll, which can interfere with the chlorophyll-red colorchlorophyll color zone, may have comigrated and covers flavonoid compounds in the sample. Further tests on the flavonoid content of n-hexane extract of $G$. bancana Miq are required.

Tetrandrine was used as the standard in the alkaloid test, but none were found (Fig. 5). $\beta$-sitosterol was used as the standard in the terpenoid

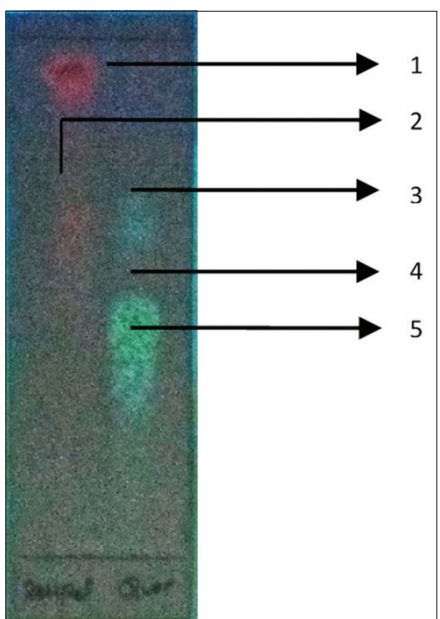

Fig. 4: The most active chromatography fraction of an n-hexane leaf extract of $G$. bancana Miq. and quercetin using a chloroform:acetone:formic acid (8:1:1) mobile phase and after spraying $\mathrm{AlCl}_{3} 5 \%$ on $366 \mathrm{~nm}$ ultraviolet light

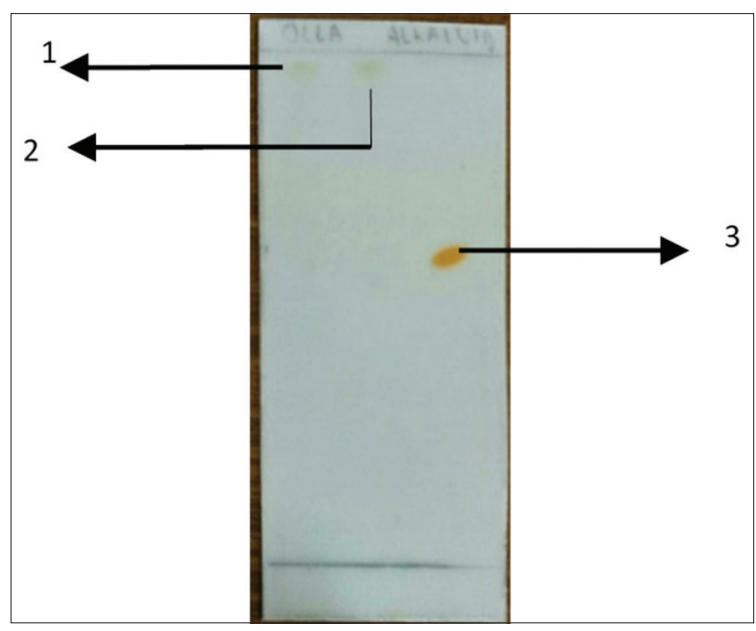

Fig. 5: The most active chromatography of an $n$-hexane leaf extract of Garcinia bancana Miq. (1). (2) and tetrandrine (3) with toluene toxic phase:ethyl acetate:methanol:ammonia (10:9:6:0.3) after spraying Dragendorff reagents 
Table 5: FRAP \% capacity and value of $\mathrm{EC}_{50}$ most active fraction

\begin{tabular}{llll}
\hline Final concentration $(\mu \mathrm{g} / \mathrm{mL})$ & Capacity percentage $(\%)$ & Linear regression equation & $0.6823 \mathrm{x}+23.019$ \\
\hline 25.725 & 42.14 & & \\
36.015 & 47.79 & & \\
51.45 & 54.53 & & \\
67.914 & 69.68 & & \\
77.175 & 77.16 & & \\
\hline
\end{tabular}

FRAP: Ferric reducing antioxidant power

Table 6: Results of phytochemical screening with TLC plates

\begin{tabular}{llll}
\hline Compound test & Standard & Mobile phase & Spray \\
\hline Flavonoid & Quercetin & Chloroform:acetone:formic acid $(8: 1: 1)$ & $\mathrm{AlCl}_{3}$ \\
Alkaloid & Boldine & Toluene:ethyl acetate: methanol:ammonia $(10: 9: 6: 0.3)$ & - \\
Terpenoid & $\beta$-sitosterol & n-Hexane: ethyl acetate $(9: 1)$ & $\mathrm{H}_{2} \mathrm{SO}_{4}-\mathrm{Vanillin}$ \\
\hline
\end{tabular}

TLC: Thin-layer chromatography

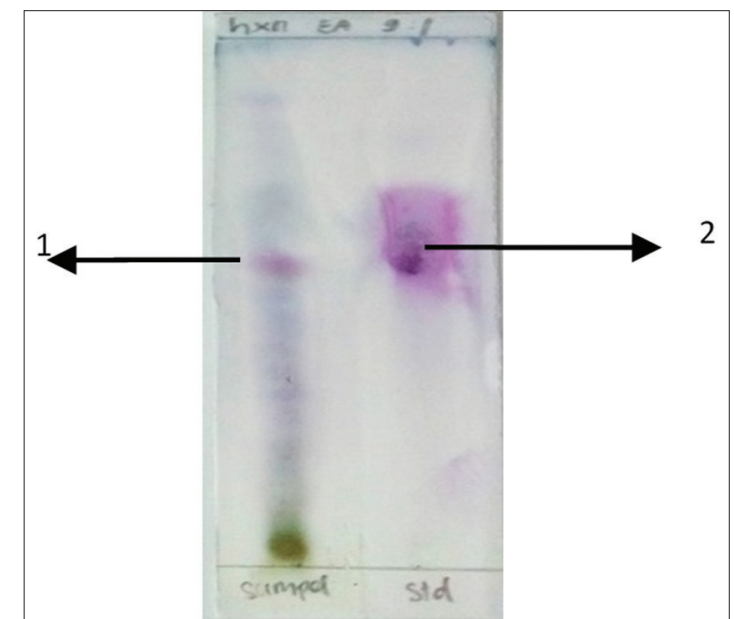

Fig. 6: The most active chromatography fraction of an n-hexane leaf extract of Garcinia bancana Miq. (1) and $\beta$-sitosterol (2) using a hexane and ethyl acetate (9:1) mobile phase and after spraying with $1 \%$ vanillin and $10 \% \mathrm{H}_{2} \mathrm{SO}_{4}$ and heating

test. The sample produced a chromatogram and color pattern similar to the standard, indicating that terpenoid group compounds were present (Fig. 6).

\section{CONCLUSION}

Antioxidant testing was repeated using the FRAP method to confirm the DPPH results. In the FRAP method, the samples with higher antioxidant also have the highest absorbance. Furthermore, the most active fraction of an n-hexane extract of the leaves of G. bancana Miq., which was tested by both DPPH and FRAP methods, had antioxidant activities with IC ${ }_{50}$ and $\mathrm{EC}_{50}$ values of $36.2482 \mu \mathrm{g} / \mathrm{mL}$ and $39.5442 \mu \mathrm{g} / \mathrm{mL}$, respectively. Phytochemical screening showed that the active fraction contains terpenoids.

\section{CONFLICTS OF INTEREST}

The authors have no conflicts of interest.

\section{REFERENCES}

1. Sen S, Chakraborty R, Sridhar C, Reddy YS, De B. Free radicals, antioxidants, diseases and phytomedicines: Current status and future prospect. Int J Pharm Sci Res 2010;3:91-100.

2. Simiati, IM. Test the Antioxidant Activity of Leaf Extract Garcinia lateriflora Blume var. Javanica Boerl. With DDPH Method and Identification of Identifikasi Chemical Compounds from Active
Fractions. Indonesia: Thesis, Faculty of Pharmacy, Universitas Indonesia; 2012.

3. Nadheesha MK, Bamunuarachchi A, Edirisinghe EM, Weerasinghe WM. Studies on antioxidant activity of Indian gooseberry fruit and seed. J Sci Univ Kelaniya Sri Lanka 2007;3:83-92.

4. Wu N, Fu K, Fu YJ, Zu YG, Chang FR, Chen YH, et al. Antioxidant activities of extracts and main components of pigeonpea (Cajanus cajan (L.) Millsp.) leaves. Molecules 2009;14:1032-43.

5. Hartati S, Masrukhan, Cahyana H. Isolation of antioxidant compounds in heaxane extract of Garcinia bancana Miq. J Kimia Ter Indones 2014;16:17-23.

6. Putri NL, Elya B, Puspitasari N. Antioxidant activity and lipoxygenase inhibition test with total flavonoid content from Garcinia kydia Roxburgh leaves extract. Pharmacogn J 2017;9:280-4.

7. Elya B, Katrin, Sauriasari R. Isolation, identification and evaluation of compounds that are efficacious as antioxidants and antidiabetes from familia Clusiaceae. Fac Pharm Univ Indones 2015.

8. Katrin H, Bendra A. The antioxidant activity of extract, fraction and class of chemical compound leaves of Premna obngata Miq. (Aktivitas antioksidan ekstrak, fraksi dan golongan senyawa kimia daun Premna obngata Miq). Pharm Sci Res 2015;2:2-11.

9. Prabhune AM, Jadhav SN, Nandikar MD, Aparadh VT. Free radical scavenging (DPPH) and ferric reducing ability (FRAP) of some Commelinaceae members. Int J Biol Pharm All Sci 2013;2:1128-34.

10. Jan AT, Kamli MR, Murtaza I, Singh JB, Ali A, Haq QM. Dietary flavonoid quercetin and associated health benefits-an overview. Food Rev Int 2010;26:302-17.

11. Muharni M, Supriyatna S, Husein HB, Dahriyanus D. Phenolic compound from the stem bark of Manggis Hutan (Garcinia bancana Miq.) and their antioxidant activity. Indo J Chem 2009;9:321-7.

12. Antolovich M, Prenzler PD, Patsalides E, McDonald S, Robards K. Methods for testing antioxidant activity. Analyst 2002;127:183-98.

13. Elya B, Rosmala D, Budiman MH. Antioxidant cream of Solanum lycopersicum L. Int J Pharm Tech Res 2013;5:233-8.

14. Lu Y, Khoo TJ, Wiart C. Antioxidant activity determination of citronellal and crude extracts of Cymbopogon citratus by 3 different methods. Pharmacol Pharm 2014;5:395-400.

15. Fidrianny I, Aristya T, dan Hartati R. Antioxidant capacities of various leaves extracts from three species of legumes and correlation with total flavonoida, phenolic, carotenoid content. Int J Pharmacogn Phytochem Res 2015;7:628-34.

16. Chanda S, Dave R. In vitro models for antioxidant activity evaluation and some medicinal plants possessing antioxidant properties: An overview. Afr J Microbiol Res 2009;3:981-96.

17. Benzie IF, Strain JJ. The ferric reducing ability of plasma (FRAP) as a measure of "antioxidant power" the FRAP assay. Anal Biochem 1996;239:70-6.

18. Halvorsen BL, Holte K, Myhrstad MC, Barikmo I, Hvattum E, Remberg SF, et al. A systematic screening of total antioxidants in dietary plants. Am Soc Nutr Sci 2002;132:461-71.

19. Scapin G, Schmidt MM, Prestes R, Rosa CS. Phenoic compounds, flavonoids and antioxidant activity of chia seed extract (Salvia hispanica) obtained by different extraction conditions. Int Food Res J 2016;23:2341-6. 
20. Elya B, Mun'im A, Hasiholan A, Marlin I. Antioxidant activities of leaves extracts of three species of Garcinia. Int J Med Arom Plants 2012;2:691-3

21. Nishaa S, Vishnupriya M, Sasikumar JM, Hephzibah PC, Gopalakrishnan VK. Antioxidant activity of ethanolic extract of Maranta arundinacea. L tuberous rhizomes. Asian J Pharm Clin Res 2012;5:85-8.

22. Sindhu S, Manorama S. Screening of Polycarpaea corymbosa Lam,
(Caryophylaceae) for its in vitro antioxidant activity. Asian J Pharm Clin Res 2012;5:175-8.

23. Thambidurai Y, Sudarsanam D, Skm H, Ashok KT. Free radical scavenging activity of marine sponges collected from Kovalam, Chennai. Asian J Pharm Clin Res 2017;10:321-7.

24. Wagner H, Bladt S. Plant Drug Analysis. $2^{\text {nd }}$ ed. Jerman: Springer; 1996. 